Review

\title{
Modes of Human T Cell Leukemia Virus Type 1 Transmission, Replication and Persistence
}

\author{
Alexandre Carpentier $^{\dagger}$, Pierre-Yves Barez ${ }^{\dagger}$, Malik Hamaidia ${ }^{\dagger}$, Hélène Gazon, Alix de Brogniez, \\ Srikanth Perike, Nicolas Gillet and Luc Willems * \\ Molecular and Cellular Epigenetics (GIGA) and Molecular Biology (Gembloux Agro-Bio Tech), \\ University of Liège (ULg), 4000 Liège, Belgium; E-Mails: a.carpentier@doct.ulg.ac.be (A.C.); \\ py.barez@ doct.ulg.ac.be (P.-Y.B.); mhamaidia@ulg.ac.be (M.H.); helene.gazon@ulg.ac.be (H.G.); \\ alix.debrogniez@ulg.ac.be (A.B.); Srikanthperike@gmail.com (S.P.); n.gillet@ulg.ac.be (N.G.) \\ $\dagger$ These authors contributed equally to this work. \\ * Author to whom correspondence should be addressed; E-Mail: luc.willems@ulg.ac.be; \\ Tel.: +32-4-3664925 or +32-81-622157.
}

Academic Editor: David Boehr

Received: 30 April 2015 / Accepted: 1 July 2015 / Published: 7 July 2015

\begin{abstract}
Human T-cell leukemia virus type 1 (HTLV-1) is a retrovirus that causes cancer (Adult T cell Leukemia, ATL) and a spectrum of inflammatory diseases (mainly HTLV-associated myelopathy_tropical spastic paraparesis, HAM/TSP). Since virions are particularly unstable, HTLV-1 transmission primarily occurs by transfer of a cell carrying an integrated provirus. After transcription, the viral genomic RNA undergoes reverse transcription and integration into the chromosomal DNA of a cell from the newly infected host. The virus then replicates by either one of two modes: (i) an infectious cycle by virus budding and infection of new targets and (ii) mitotic division of cells harboring an integrated provirus. HTLV-1 replication initiates a series of mechanisms in the host including antiviral immunity and checkpoint control of cell proliferation. HTLV-1 has elaborated strategies to counteract these defense mechanisms allowing continuous persistence in humans.
\end{abstract}

Keywords: HTLV-1; viral replication; viral persistence; Tax; HBZ 


\section{Introduction}

HTLV-1 infects approximately 5-10 million people worldwide mainly in subtropical areas [1]. In the vast majority of cases, HTLV-1 infection remains clinically silent. Among asymptomatic carriers, $3 \%$ to $5 \%$ will develop a leukemia/lymphoma (ATL) or a neurodegenerative disease (HAM/TSP) after long latent periods (40-60 years) [2]. ATL results from proliferation and accumulation of infected cells carrying an integrated proviral genome (here referred to as clones). HAM/TSP is associated with invasion of the central nervous system by infected cells, antiviral immunity, cytokine burst, and inflammation. Main clinical symptoms of HAM/TSP are urinary failures and paralysis of lower legs. Why infected subjects develop either ATL or HAM/TSP is currently unknown. There is no efficient treatment for HAM/TSP, except palliative attenuation of inflammation with corticosteroids. The leukemic form of ATL is initially responsive to general chemotherapy (CHOP) but almost invariably relapses after a few months. An antiviral therapy based on AZT combined with interferon yields 50\% survival at five years [3]. Another type of treatment includes hematopoietic stem cell transplantation that yields, if successful, the best long-term survival rates [4-6]. An anti-CCR4 antibody is now in clinical use in Japan $[7,8]$ and other promising approaches such as valproic acid are currently being investigated $[8,9]$.

The HTLV-1 genome contains essential structural and enzymatic genes (Gag, Pro, Pol and Env) shared by all retroviral family members (reviewed by [10]). As a deltaretrovirus, HTLV-1 also encodes a series of accessory and regulatory proteins. Among these, the Tax oncoprotein and HTLV-1 basic leucine zipper factor (HBZ) play pivotal roles in the viral life cycle [11]. Here, we describe how these factors subvert cellular pathways to allow viral transmission, persistence, and replication.

\section{Current Model of HTLV-1 Replication}

HTLV-1 predominantly infects CD4+ T cells but also targets other cell types such as CD8+ T and B lymphocytes, dendritic cells (DCs), monocytes, and macrophages [12-14]. This pleiotropic pattern is permitted by the presence of membrane-associated receptors that interact with the viral envelope allowing efficient binding and entry. These include heparan sulfate proteoglycans (HSPGs), the glucose transporter 1 (GLUT-1) and neuropilin-1 (NRP-1) [15-18]. The mechanisms of receptor binding and virus entry have been reviewed elsewhere [19-21]. A number of studies have shown that cell-free infection is poorly efficient compared to cell-to-cell virus transfer (about 10,000 fold) [22,23], suggesting that HTLV-1 spread in vivo relies more on a cellular intermediate than on the virion itself. Whatever the route of infection used, the initial contact with HTLV-1 mainly occurs via breast feeding, sexual intercourse, and blood transfusion [24]. Except when contamination occurs by blood transfer, initial infection first requires interaction with oral, gastrointestinal, or cervical mucosa. Crossing of the mucosal barrier occurs by different mechanisms as schematized on Figure 1a. Although not formally demonstrated yet, HTLV-1 infected macrophages could transmigrate through an intact epithelium as observed for human immunodeficiency virus (HIV) [25,26]. Viral particles produced by HTLV-1 infected T-cells have been shown to cross the epithelium by transcytosis, i.e., the transit of a virion incorporated into a vesicle from the apical to the basal surface of an epithelial cell [26,27]. Alternatively, HTLV-1 can also infect an epithelial cell and produce new virions that are then released from the basal surface [28]. Finally, HTLV-1 infected cells can directly bypass a disrupted mucosa [28]. 

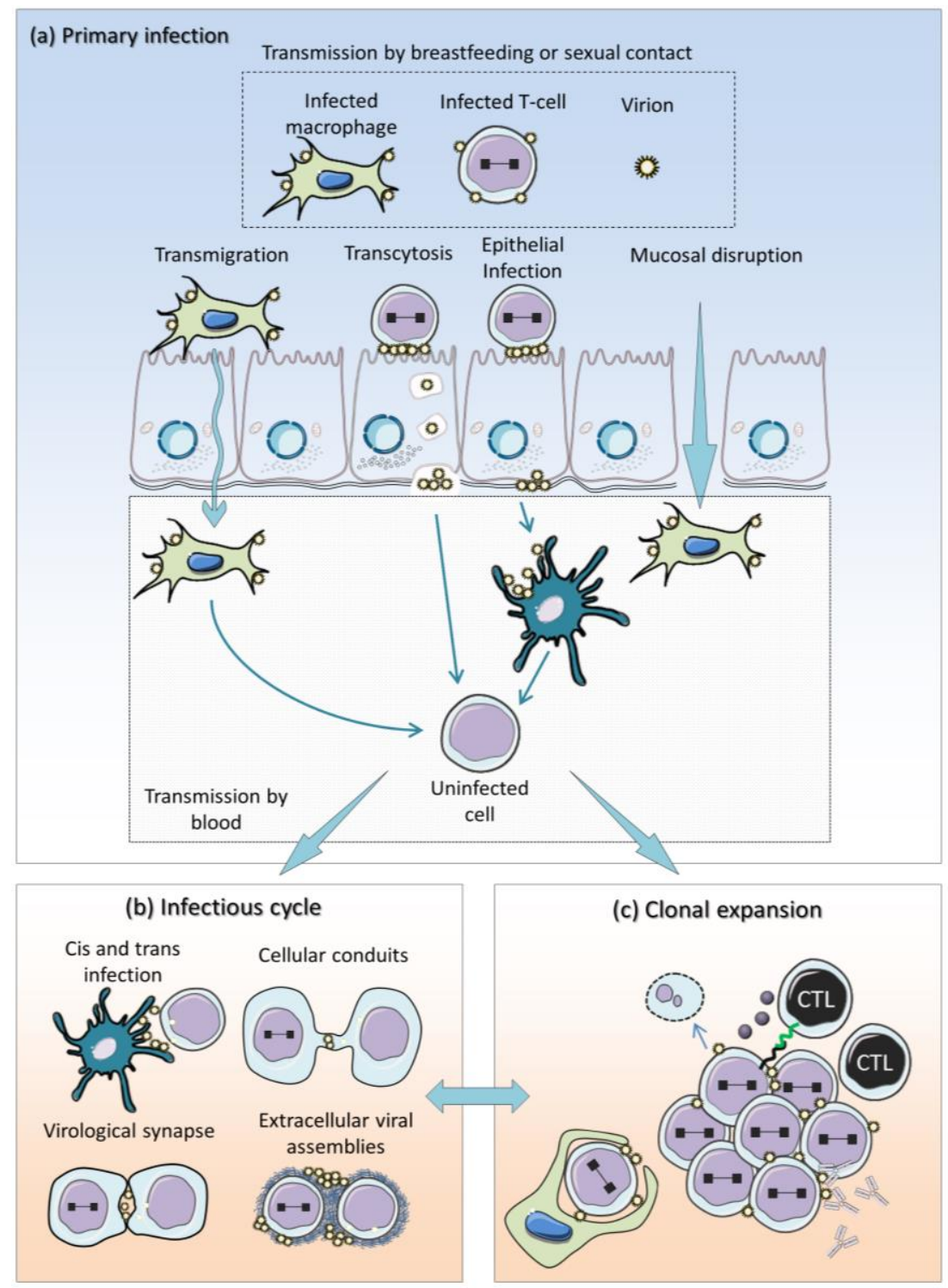

Figure 1. Model of HTLV-1 replication (a) HTLV-1 transmission occurs by breastfeeding, sexual intercourse, or blood transfusion. Except for blood transfer, initial infection requires crossing of the mucosal barrier by several mechanisms: (i) transmigration of HTLV-1 infected macrophages, (ii) transcytosis of viral particles, (iii) release of newly produced virions from the basal surface of infected epithelial cell, (iv) bypass of HTLV-1 infected cells through a damaged mucosa. HTLV-1 can then infect mucosal immune cells directly (cis-infection) or via antigen-presenting cells (APCs); (b) APCs can either become infected or transfer membrane-bound extracellular virions to T-cells (trans-infection). Cell-to-cell transfer of virions involves different non-exclusive mechanisms: a virological synapse, cellular conduits, or extracellular viral assemblies. Infection of resident cells occurs either in the mucosa or in secondary lymphoid organs. Soon after primary infection, HTLV-1 replicates by cell-to-cell infection (i.e., the infectious cycle) or (c) by mitotic division of a cell containing an integrated provirus (clonal expansion). Since an antiviral immune response is quickly initiated, the efficacy of the infectious cycle is severely dampened down soon after infection. 
Having crossed the epithelial barrier, HTLV-1 infects mucosal immune cells directly or via APCs such as DCs or macrophages. APCs can either undergo infection or transfer membrane bound extracellular virions to uninfected T-cells (trans-infection) [14]. Cell-to-cell transfer of HTLV-1 virions then potentially involves several non-exclusive mechanisms (reviewed in [28]): a virological synapse [29-31], cellular conduits [32], or extracellular viral assemblies [33,34]. Infection of resident cells occurs either in the mucosa or in secondary lymphoid organs.

Soon after primary infection, HTLV-1 attempts to expand by colonizing new targets by cell-to-cell transfer, reverse transcription of the viral RNA, integration of the provirus into the chromosome, expression of viral proteins and budding of new virions (the infectious cycle; Figure 1b). Another mode of replication involves mitotic division of a cell containing an integrated provirus (clonal expansion; Figure 1c). Recently, host restriction factors such as SAMHD1, APOBEC3 and miR-28-3p have been shown to limit HTLV-1 infection [35-37]. Since an antiviral immune response is also quickly initiated, the efficacy of the infectious cycle is severely attenuated soon after infection, although likely not completely abrogated later on. On the other side, clonal expansion and cell proliferation also require expression of viral factors such as Tax [38,39]. Survival of infected progeny cells therefore requires silencing of viral expression before immune-mediated destruction. This model is consistent with the following observations: (i) to block HTLV-1 infection, reverse transcriptase inhibitors (RTIs) must be administrated simultaneously with viral inoculation [40]; (ii) when used alone, RTIs do not reduce the proviral load in HTLV-1 infected subjects [41,42]; (iii) sustained T-cell proliferation in patients correlates with Tax expression [43], extending previous studies in BLV-infected animal models [44]; (iv) compared to HIV, the HTLV-1 genome undergoes limited variability [45], suggesting a replication mode by cellular DNA polymerase rather than by viral reverse transcriptase; (v) sequential high-throughput sequencing of proviral integration sites reveal a high clonal stability over years [46]. In this context, our recent study in BLV-infected cows also showed that most clones generated during primary infection are destroyed and replaced by others undergoing expansion [47].

Taken together, these data support a model of viral replication by cell-to-cell contact at the early stages of infection, followed by a sustained clonal proliferation counterbalancing the host immune response. Repetitive cycles of viral expression followed by transcriptional silencing continuously challenges the immune response thereby initiating inflammation and ultimately leading to HAM/TSP. By favoring emergence of sporadic mutations in the cell genome, unrestrained proliferation also paves the way to malignant transformation and development of ATL [43].

\section{Tax and HBZ Are Two Main Drivers of Viral Replication}

According to currently most accepted model, Tax and HBZ are believed to have the highest impact on viral replication and cell transformation, besides other components required to synthesize the viral particle. The modes of action of Tax and HBZ are remarkably pleiotropic and involve a variety of cell signaling pathways (CREB, NFkB and AKT; Figure 2). Tax inhibits tumor suppressors (p53, Bc111B and TP53INP1 [48-50]) and activates cyclin-dependent kinases (CDKs) [51], both of these mechanisms leading to accelerated cell proliferation. In parallel, Tax attenuates the Mad1 spindle assembly checkpoint protein, induces genomic lesions and interferes with DNA repair thereby promoting aneuploidy [39,52,53]. Experimental evidence also shows that Tax drives tumor formation in transgenic 
mouse models, supporting its oncogenic potential [54-56]. Tax also induces genomic instability [39,57], generating somatic alterations [58] and promoting cell growth. However, expression of Tax alone fails to systematically immortalize human primary T cells [59], suggesting the involvement of other viral or cellular components. In particular, driver mutations affecting the CCR4 chemokine receptor have been identified in $\sim 25 \%$ of ATL cases [60,61]. In about $50 \%$ of ATL cases, Tax is either inactivated by genetic mutation or transcriptionally silenced by hyper-methylation or deletion of the 5'-LTR [62-65]. Because of the strong immunogenicity of the Tax protein, it is possible that these mechanisms confer a selective advantage to HTLV-1-transformed T cells [66-69]. In comparison, HBZ triggers a less efficient immunity that is compatible with permanent expression throughout HTLV-1 infection [70,71]. Later in leukemogenesis, cell growth can thereby become independent of Tax and be promoted by HBZ. Indeed, HBZ is constitutively expressed throughout HTLV-1 infection [72,73], counteracts Tax-mediated viral and cellular pathways modulation (such as NF- $\mathrm{KB}$, Akt and CREB) and stimulates cell proliferation $[69,74]$ via apoptosis/senescence inhibition and cell cycle modulation $[69,74]$. This simplified model thus hypothesizes that Tax initiates transformation while HBZ is required to maintain the transformed phenotype if Tax expression is silenced [75]. Clinical data indicating that Tax mRNA expression allows estimating the risk of HAM/TSP development and that HBZ positively correlates with the severity of symptoms further supports a role of Tax and HBZ in pathogenesis [76,77].

\subsection{Tax and HBZ Exert Opposite Functions in Signaling Pathways}

Almost systematically, the activities of Tax on a series of cellular pathways are balanced by HBZ.

\subsubsection{NF-KB}

By controlling $\mathrm{T}$ lymphocyte activation and proliferation in response to diverse immune stimuli (such as antigens, cytokines or microbial components), the NF- $\mathrm{BB}$ pathway is a key player in regulation of immunity and inflammation [78]. HTLV-1 Tax activates the IKK complex through IKK $\gamma / \mathrm{NEMO}$ binding. Tax requires CADM1/TSLC1 for inactivation of the NF-kappaB inhibitor A20 and constitutive NF- $\kappa B$ signaling [79]. The subsequent translocation of $\mathrm{p} 50 / \mathrm{p} 65$ complex into the nucleus activates transcription of NF- $\kappa B$ responsive genes $[78,80]$. Activation of the canonical NF- $\kappa B$ pathway by Tax requires IL17RB signaling [81]. On the other hand, Tax stimulates IKK $\alpha$-dependent processing of p100 into p52 $[78,80]$. Tax also hijacks the cellular ubiquitin machinery to activate ubiquitin-dependent kinases and NF- KB signaling (reviewed in [82]). Tax thereby induces expression of a variety of growth promoting cytokines (such as IL-1, IL-6, TNF, and EGF [83,84]). Tax also upregulates antiapoptotic proteins: caspase- 8 inhibitory protein c-FLIP [85,86] and members of the Bcl-2 family (Bcl-2, Bcl-xL, Mcl-1 and Blf-1) [87-90]. By activating the NF- $\kappa$ B pathway, Tax thus favors proliferation and survival of HTLV-1-infected T cells. On the contrary, HBZ suppresses the canonical NF- $\kappa B$ signaling pathway by inhibiting the activity of the RelA/p65 complex and thus mitigates excessive activation of NF- $\mathrm{B}$ by Tax [91]. NF- KB activation by Tax is associated with an upregulation of $\mathrm{p} 21^{\mathrm{WAF} 1 / \mathrm{CIP} 1}$ and $\mathrm{p} 27^{\mathrm{KIP} 1}$, leading to cellular senescence [92,93]. In HeLa cells, HBZ prevents Tax-induced senescence through down-regulation of NF-KB $[92,94]$. 


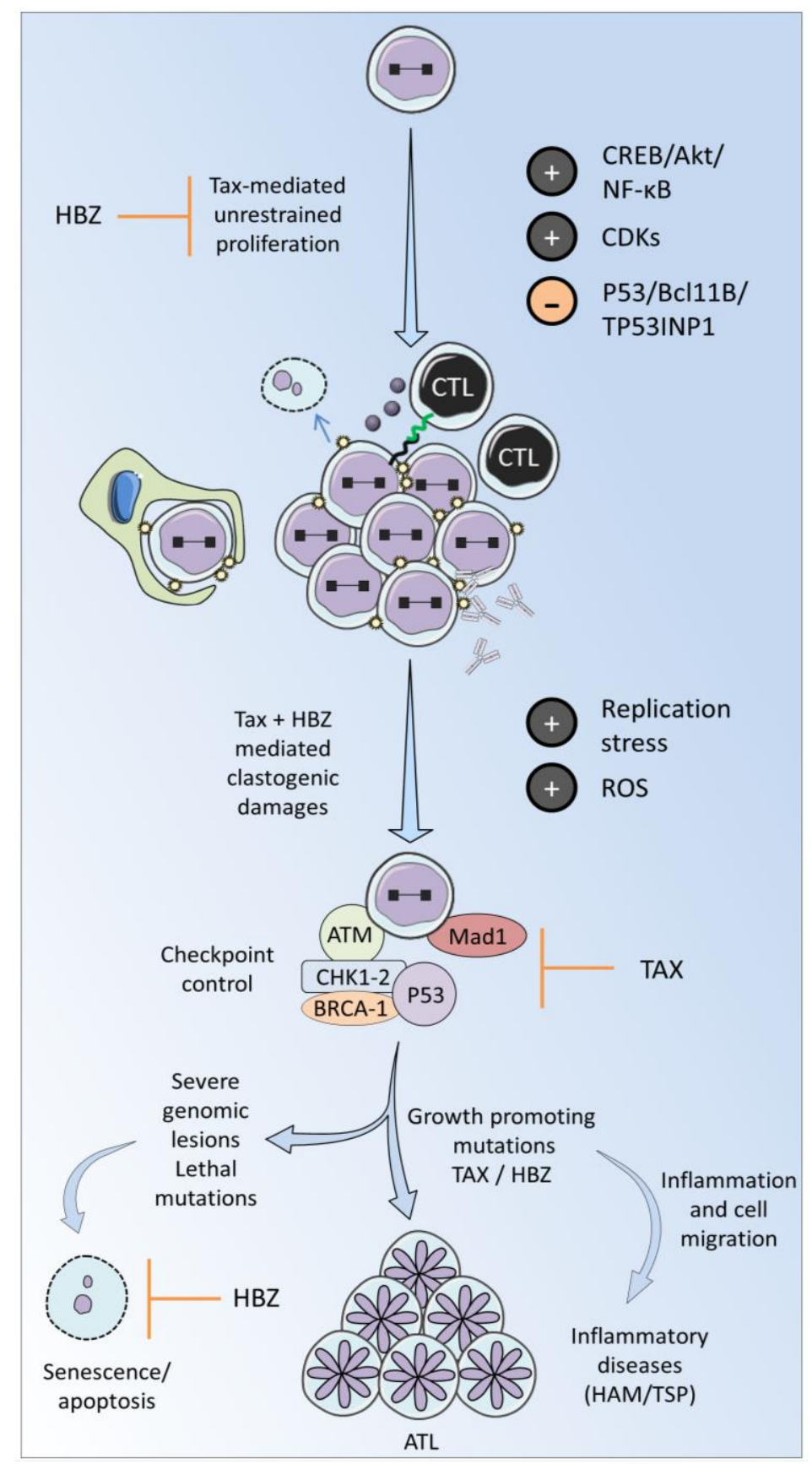

Figure 2. Tax and HBZ promote proliferation and persistence of the infected cell. Tax activates survival pathways (CREB/Akt/NFkB), promotes mitosis (CDKs), and inhibits tumor suppressors (p53, TP53INP1, Bcl11B). Tax-mediated growth-promoting activities are counteracted by HBZ, mitigating unrestrained proliferation. The host immune response further controls infected cell proliferation. Tax-induced proliferation creates replicative stress and generates reactive oxygen species (ROS). Tax interacts with the mitotic checkpoint control protein Mad1 thereby inducing clastogenic damage. Tax attenuates the DNA damage response (DDR) induced by unscheduled cell proliferation. Inhibition of the DDR allows cells to accumulate DNA lesions and stabilize mutations. If uncontrolled by senescence or cell death mechanisms, growth-promoting mutations pave the way to disease development. 


\subsubsection{Akt}

Tax promotes cell proliferation and survival through activator protein-1 (AP-1) and the phosphatidylinositol 3-kinase (PI3K)/Akt pathway [95]. Inhibition of Akt in HTLV-1-transformed cells decreases phosphorylated Bad and induces caspase-dependent apoptosis [96]. Stimulation of PI3K/Akt by Tax activates HiF-1 (hypoxia-inducible factor 1) [97], reduces expression of proapoptotic Bim and Bid and promotes IL-2 independent growth [98] and finally increases Bcl3 whose expression is associated with the growth of infected cells [99]. HBZ inhibits Tax-dependent activation of the PI3K/Akt pathway and downstream anti-apoptotic properties [100]. HBZ suppresses apoptosis by attenuating the function of FOXO3a and altering its localization [101]. Besides, the interaction of HBZ with AP-1 factors (cJun, JunB or MafB) results in the inhibition of their transcriptional activities via several mechanisms, such as sequestration into nuclear bodies or proteasomal degradation, and prevents the subsequent activation of AP-1 regulated genes [102-106].

\subsubsection{CREB}

Tax activates 5'-LTR-directed transcription by interacting with CREB, modulating its phosphorylation at Ser133 and connecting the histone acetyltransferase CBP (CREB-binding protein/p300) [107]. The ability of Tax to activate transcription via CREB is required to protect murine fibroblasts from serum-depletion-induced apoptosis. [108-110]. Tax modifies the phosphorylation state of CREB (i) by activating the upstream Akt kinase [111,112] or (ii) by decreasing the expression of PTEN phosphatase which is required for CREB dephosphorylation at Ser133 in the nucleus [111,113].

HBZ represses viral transcription through interaction with the bZIP domain of CREB proteins and prevents their binding to the viral CRE elements [114,115]. HBZ interacts with the KIX domain of p300/CBP, competing for Tax binding and inhibiting the association of co-activators with the viral promoter [116]. HBZ modulates the occupancy of KIX domains of p300/CBP by modulating the activity of transcription factors, thereby influencing subsequent gene expression [117].

\subsubsection{Wnt}

Tax interacts with DAPLE (dishevelled-associating protein with a high frequency of leucine residues) to activate the canonical Wnt pathway. HBZ can suppress this activation by inhibiting DNA binding of TCF-1/LEF-1 transcription factors. On the other side, HBZ promotes transcription of WnT 5a, a key protein of the non-canonical Wnt pathway, by enhancing its promoter activity through transforming growth factor-beta (TGF-beta). Knockdown of Wnt5a represses proliferation and migration of ATL cells, pointing out the role of this pathway in HTLV-1 infected cell growth [118].

\subsubsection{TGF- $\beta / \mathrm{Smad}$}

Tax represses TGF- $\beta 1$ signaling (i) by blocking the association of Smad proteins with Smad-binding elements, (ii) through its interaction with CREB-binding protein/p300 and (iii) via c-jun activation [119-121]. HBZ counteracts this effect and also interacts with Smad2/3 to enhance TGF-beta/Smad transcriptional responses in a p300-dependent manner, improving transcription of different genes, such as the FOXP3 mediator of regulatory T cells [122]. 


\subsubsection{S Phase Entry and Cell Cycle Progression}

Through interaction with cyclins and CDKs, Tax interferes with cell cycle progression by several mechanisms: (i) Tax stabilizes the cyclin D2/CDK4 complex and favors hyperphosphorylation of the retinoblastoma protein $(\mathrm{Rb})$. Phosphorylated $\mathrm{Rb}$ frees E2F1 that activates transcription of genes required for G1/S transition; (ii) Tax represses cyclin-dependent kinases inhibitors (CKIs) such as members of INK4 family and KIP1; (iii) Tax interacts with and directs Rb to the proteasome for subsequent degradation; (iv) Tax activates the cyclin D1 transcription by enhancing p300 recruitment to the CRE site of cyclin D1 promoter through interaction with pCREB and TORC2 [123]. As a result, Tax favors $S$ phase entry of HTLV-1 infected cells (reviewed in [51,75]). Tax also accelerates $S$ phase progression by interaction with the replicative helicase (minichromosome maintenance complex, MCM2-7). Tax modulates the spatiotemporal program of replication origins through $\mathrm{p} 300$-dependent histone hyperacetylation, resulting in early firing of late replication origins. Tax also fires supplementary origins of replication accelerating $\mathrm{S}$ phase progression. This mechanism triggers replicative stress and genomic lesions, such as double strand breaks (DSBs) [39,57]. By modulating replication timing, Tax could also modulate the entire transcriptional landscape of infected cells. Indeed, the level of transcription at replication origins (ORC1 binding sites) correlates with replication timing [124].

In contrast to Tax, HBZ exerts a dual regulatory role in cell cycle progression. Indeed, HBZ interacts with CREB and inhibits transcription of cyclin D1 [125]. HBZ also binds activating transcription factor 3 (ATF3) that modulates expression of cell division cycle 2 (CDC2) and cyclin E2, thereby promoting proliferation of ATL cells [126]. Concomitantly, HBZ suppresses ATF3-induced p53 transcriptional activity. Moreover, the HBZ mRNA increases E2F1 gene transcription and promotes cell proliferation [69].

Together, this series of data on the signaling pathways illustrates the opposite functions of Tax and HBZ in finely tuned regulatory mechanisms of cell proliferation.

\subsection{Cellular Checkpoints Control Unscheduled Proliferation}

Cellular checkpoints act as a failsafe barrier against unrestrained cellular proliferation. Tax subverts the G1 restriction and the spindle mitotic checkpoints. In G1, the tumor-suppressor protein p53 is the main factor that controls the checkpoint. Although approximately $50 \%$ of cancers harbor a mutation in p53, this mechanism only appears in a small percentage of ATL patients. Instead, p53 is functionally inactivated in leukemic and HTLV-1 transformed cells [127]. It remains incompletely understood how Tax inactivates p53: (i) Tax competes with p53 in binding with CBP, thereby repressing p53 trans-activating function [128]; (ii) NF-kappaB p65 subunit is critical for Tax-induced p53 inactivation [129]; (iii) repression of p53 transcriptional activity by Tax is independent of NF-kB and CBP [130]; p53 is invalidated by wild-type p53-induced phosphatase 1 (Wip1) [131,132]. ATL cells are characterized by loss of spindle assembly checkpoint function [133] and aneuploidy [134]. Tax binding to Mad1 perturbs the organization of the spindle assembly and results in multinucleated cells [52]. Moreover, the direct interaction between Tax and the anaphase-promoting complex APC Cdc20 also explains the mitotic abnormalities in HTLV-1 infected cells [135]. Tax promotion of supernumerary 
centrosomes through recruitment of Ran and Ran-binding protein-1 is another mechanism contributing to leukemia [136].

\subsection{Response to DNA Damage}

By accelerating the replication-timing program, the Tax protein induces replicative stress and DSBs [39]. Tax expression generates reactive oxygen species (ROS) leading to oxidative and replication-dependent DSBs [53]. Tax-associated DNA damages activate several phosphoproteins of the DDR pathway (H2AX, ATM, CHK1-2, P53, BRCA1), which in turn arrest the cell cycle transiently or lead to apoptosis and senescence. In presence of DNA damaging agents (e.g., UV irradiation), Tax inhibits the DDR machinery by sequestrating key signaling pathway components [137-144]. Induction of genomic lesions and inhibition of the DDR leads to proliferation in presence of DNA mutations, potentially to leukemogenesis.

HBZ induces DNA lesions through activation of miR-17 and miR-21 and downregulation of the DNA damage factor OBFC2A [145]. HBZ association with growth arrest and DNA damage gene 34 (GADD34) also deregulates the cellular responses to DNA damage [146].

\subsection{DNA Repair Pathways}

Besides modulating the DDR signaling pathway, Tax also directly interferes with the mechanisms of DNA repair. For example, Tax downregulates the expression of $\beta$-polymerase [147] and inhibits base excision repair (BER) [148]. Furthermore, Tax activates PCNA and interferes with nucleotide excision repair (NER) [149,150]. Tax decreases Ku80 gene transcription and interacts with Ku80 protein, interfering with non-homologous end joining (NHEJ) [151,152]. In Tax-expressing cells, DSBs are nevertheless preferentially repaired by error-prone NHEJ [153]. Another viral protein, p30, inhibits homologous recombination, shifting repair towards unfaithful pathways [154]. Whether HBZ also interferes with DNA damage repair mechanisms remains to be further clarified.

\section{Conclusions}

HTLV-1 persists and replicates by means of viral proteins, such as Tax and HBZ that finely tune cellular signaling pathways. Viral replication through the infectious and the mitotic routes requires viral expression and faces destruction by the host immune response. Expression of viral proteins creates genomic stress responsible for DNA lesions that initiate the DDR response. Imperfect repair of these errors stabilizes mutations that potentially drive oncogenesis.

\section{Acknowledgments}

This work was supported by the "Fonds National de la Recherche Scientifique" (FNRS), the Télévie, the Interuniversity Attraction Poles (IAP) Program "Virus-host interplay at the early phases of infection" BELVIR initiated by the Belgian Science Policy Office, the Belgian Foundation against Cancer (FBC), the Sixth Research Framework Programme of the European Union (project "The role of infections in cancer" INCA LSHC-CT-2005-018704), the "Neoangio" excellence program and the "Partenariat Public Privé", PPP INCA, of the "Direction générale des Technologies, de la Recherche et de l'Energie/DG06" 
of the Walloon government, the "Action de Recherche Concertée Glyvir" (ARC) of the "Communauté française de Belgique", the "Centre anticancéreux près ULg" (CAC), the "Subside Fédéral de Soutien à la Recherche Synbiofor and Agricultureislife" projects of Gembloux Agrobiotech (GxABT), the "ULg Fonds Spéciaux pour la Recherche", the "Plan Cancer" of the "Service Public Fédéral". A.C.; S.P. and A.B. are supported by grants of the Télévie. M.H. is a research fellow of the "Agriculture is life" project of GxABT. N.G. is supported by the IAP program. P.-Y. B. (FNRS research fellow), H.G. (post-doctoral researcher) and L.W. (Research Director) are members of the FNRS

\section{Author Contributions}

A.C.; P.-Y.B. and M.H. drafted the manuscript. L.W. edited the manuscript. All authors corrected, edited and approved the text.

\section{Conflicts of Interest}

The authors declare no conflict of interest.

\section{References}

1. Gessain, A.; Cassar, O. Epidemiological Aspects and World Distribution of HTLV-1 Infection. Front. Microbiol. 2012, 3, e388. [CrossRef] [PubMed]

2. Verdonck, K.; Gonzalez, E.; Van Dooren, S.; Vandamme, A.M.; Vanham, G.; Gotuzzo, E. Human T-lymphotropic virus 1: Recent knowledge about an ancient infection. Lancet. Infect. Dis. 2007, 7, 266-281. [CrossRef]

3. Bazarbachi, A.; Plumelle, Y.; Carlos Ramos, J.; Tortevoye, P.; Otrock, Z.; Taylor, G.; Gessain, A.; Harrington, W.; Panelatti, G.; Hermine, O. Meta-analysis on the use of zidovudine and interferon-alfa in adult T-cell leukemia/lymphoma showing improved survival in the leukemic subtypes. J. Clin. Oncol. 2010, 28, 4177-4183. [CrossRef] [PubMed]

4. Shiratori, S.; Yasumoto, A.; Tanaka, J.; Shigematsu, A.; Yamamoto, S.; Nishio, M.; Hashino, S.; Morita, R.; Takahata, M.; Onozawa, M.; et al. A retrospective analysis of allogeneic hematopoietic stem cell transplantation for adult $\mathrm{T}$ cell leukemia/lymphoma (ATL): Clinical impact of graft-versus-leukemia/lymphoma effect. Biol. Blood Marrow Transpl. 2008, 14, 817-823. [CrossRef] [PubMed]

5. Ishida, T.; Hishizawa, M.; Kato, K.; Tanosaki, R.; Fukuda, T.; Takatsuka, Y.; Eto, T.; Miyazaki, Y.; Hidaka, M.; Uike, N.; et al. Impact of graft-versus-host disease on allogeneic hematopoietic cell transplantation for adult $\mathrm{T}$ cell leukemia-lymphoma focusing on preconditioning regimens: Nationwide retrospective study. Biol. Blood Marrow Transpl. 2013, 19, 1731-1739. [CrossRef] [PubMed]

6. Ishida, T.; Hishizawa, M.; Kato, K.; Tanosaki, R.; Fukuda, T.; Taniguchi, S.; Eto, T.; Takatsuka, Y.; Miyazaki, Y.; Moriuchi, Y.; et al. Allogeneic hematopoietic stem cell transplantation for adult T-cell leukemia-lymphoma with special emphasis on preconditioning regimen: A nationwide retrospective study. Blood 2012, 120, 1734-1741. [CrossRef] [PubMed] 
7. Utsunomiya, A.; Choi, I.; Chihara, D.; Seto, M. Recent advances in the treatment of adult T-cell leukemia-lymphomas. Cancer Sci. 2015, 106, 344-351. [CrossRef] [PubMed]

8. Yamauchi, J.; Coler-Reilly, A.; Sato, T.; Araya, N.; Yagishita, N.; Ando, H.; Kunitomo, Y.; Takahashi, K.; Tanaka, Y.; Shibagaki, Y.; et al. Mogamulizumab, an anti-CCR4 antibody, targets human T-lymphotropic virus type 1-infected CD8+ and CD4+ T cells to treat associated myelopathy. J. Infect. Dis. 2015, 211, 238-248. [CrossRef] [PubMed]

9. Lezin, A.; Gillet, N.; Olindo, S.; Signate, A.; Grandvaux, N.; Verlaeten, O.; Belrose, G.; de Carvalho Bittencourt, M.; Hiscott, J.; Asquith, B.; et al. Histone deacetylase mediated transcriptional activation reduces proviral loads in HTLV-1 associated myelopathy/tropical spastic paraparesis patients. Blood 2007, 110, 3722-3728. [CrossRef] [PubMed]

10. Katz, R.A.; Skalka, A.M. Generation of Diversity in Retroviruses. Annu. Rev. Genet. 1990, 24 , 409-443. [CrossRef] [PubMed]

11. Matsuoka, M.; Jeang, K.T. Human T-cell leukaemia virus type 1 (HTLV-1) infectivity and cellular transformation. Nat. Rev. Cancer 2007, 7, 270-280. [CrossRef] [PubMed]

12. Macatonia, S.E.; Cruickshank, J.K.; Rudge, P.; Knight, S.C. Dendritic cells from patients with tropical spastic paraparesis are infected with HTLV-1 and stimulate autologous lymphocyte proliferation. AIDS Res. Hum. Retrovir. 1992, 8, 1699-1706. [CrossRef] [PubMed]

13. Koyanagi, Y.; Itoyama, Y.; Nakamura, N.; Takamatsu, K.; Kira, J.; Iwamasa, T.; Goto, I.; Yamamoto, N. In vivo infection of human T-cell leukemia virus type I in non-T cells. Virology 1993, 196, 25-33. [CrossRef] [PubMed]

14. Jones, K.S.; Petrow-Sadowski, C.; Huang, Y.K.; Bertolette, D.C.; Ruscetti, F.W. Cell-free HTLV-1 infects dendritic cells leading to transmission and transformation of CD4+ T cells. Nat. Med. 2008, 14, 429-436. [CrossRef] [PubMed]

15. Manel, N.; Kim, F.J.; Kinet, S.; Taylor, N.; Sitbon, M.; Battini, J.L. The ubiquitous glucose transporter GLUT-1 is a receptor for HTLV. Cell 2003, 115, 449-459. [CrossRef]

16. Jones, K.S.; Petrow-Sadowski, C.; Bertolette, D.C.; Huang, Y.; Ruscetti, F.W. Heparan sulfate proteoglycans mediate attachment and entry of human T-cell leukemia virus type 1 virions into CD4+ T cells. J. Virol. 2005, 79, 12692-12702. [CrossRef] [PubMed]

17. Ghez, D.; Lepelletier, Y.; Lambert, S.; Fourneau, J.M.; Blot, V.; Janvier, S.; Arnulf, B.; van Endert, P.M.; Heveker, N.; Pique, C.; et al. Neuropilin-1 is involved in human T-cell lymphotropic virus type 1 entry. J. Virol. 2006, 80, 6844-6854. [CrossRef] [PubMed]

18. Lambert, S.; Bouttier, M.; Vassy, R.; Seigneuret, M.; Petrow-Sadowski, C.; Janvier, S.; Heveker, N.; Ruscetti, F.W.; Perret, G.; Jones, K.S.; et al. HTLV-1 uses HSPG and neuropilin-1 for entry by molecular mimicry of VEGF165. Blood 2009, 113, 5176-5185. [CrossRef] [PubMed]

19. Ghez, D.; Lepelletier, Y.; Jones, K.S.; Pique, C.; Hermine, O. Current concepts regarding the HTLV-1 receptor complex. Retrovirology 2010, 7, e99. [CrossRef] [PubMed]

20. Jones, K.S.; Lambert, S.; Bouttier, M.; Benit, L.; Ruscetti, F.W.; Hermine, O.; Pique, C. Molecular aspects of HTLV-1 entry: Functional domains of the HTLV-1 surface subunit (SU) and their relationships to the entry receptors. Viruses 2011, 3, 794-810. [CrossRef] [PubMed]

21. Hoshino, H. Cellular Factors Involved in HTLV-1 Entry and Pathogenicit. Front. Microbiol. 2012, 3, e222. [CrossRef] [PubMed] 
22. Derse, D.; Hill, S.A.; Lloyd, P.A.; Chung, H.; Morse, B.A. Examining human T-lymphotropic virus type 1 infection and replication by cell-free infection with recombinant virus vectors. J. Virol. 2001, 75, 8461-8468. [CrossRef] [PubMed]

23. Mazurov, D.; Ilinskaya, A.; Heidecker, G.; Lloyd, P.; Derse, D. Quantitative comparison of HTLV-1 and HIV-1 cell-to-cell infection with new replication dependent vectors. PLoS Pathog. 2010, 6, e1000788. [CrossRef] [PubMed]

24. Goncalves, D.U.; Proietti, F.A.; Ribas, J.G.; Araujo, M.G.; Pinheiro, S.R.; Guedes, A.C.; Carneiro-Proietti, A.B. Epidemiology, treatment, and prevention of human T-cell leukemia virus type 1-associated diseases. Clin. Microbiol. Rev. 2010, 23, 577-589. [CrossRef] [PubMed]

25. Takeuchi, H.; Takahashi, M.; Norose, Y.; Takeshita, T.; Fukunaga, Y.; Takahashi, H. Transformation of breast milk macrophages by HTLV-I: Implications for HTLV-I transmission via breastfeeding. Biomed. Res. 2010, 31, 53-61. [CrossRef] [PubMed]

26. Tugizov, S.M.; Herrera, R.; Veluppillai, P.; Greenspan, D.; Soros, V.; Greene, W.C.; Levy, J.A.; Palefsky, J.M. Differential transmission of HIV traversing fetal oral/intestinal epithelia and adult oral epithelia. J. Virol. 2012, 86, 2556-2570. [CrossRef] [PubMed]

27. Martin-Latil, S.; Gnadig, N.F.; Mallet, A.; Desdouits, M.; Guivel-Benhassine, F.; Jeannin, P.; Prevost, M.C.; Schwartz, O.; Gessain, A.; Ozden, S.; et al. Transcytosis of HTLV-1 across a tight human epithelial barrier and infection of subepithelial dendritic cells. Blood 2012, 120, 572-580. [CrossRef] [PubMed]

28. Pique, C.; Jones, K.S. Pathways of cell-cell transmission of HTLV-1. Front. Microbiol. 2012, 3, e378. [CrossRef] [PubMed]

29. Igakura, T.; Stinchcombe, J.C.; Goon, P.K.; Taylor, G.P.; Weber, J.N.; Griffiths, G.M.; Tanaka, Y.; Osame, M.; Bangham, C.R. Spread of HTLV-I between lymphocytes by virus-induced polarization of the cytoskeleton. Science 2003, 299, 1713-1716. [CrossRef] [PubMed]

30. Majorovits, E.; Nejmeddine, M.; Tanaka, Y.; Taylor, G.P.; Fuller, S.D.; Bangham, C.R. Human T-lymphotropic virus-1 visualized at the virological synapse by electron tomography. PLoS ONE 2008, 3, e2251. [CrossRef] [PubMed]

31. Nejmeddine, M.; Negi, V.S.; Mukherjee, S.; Tanaka, Y.; Orth, K.; Taylor, G.P.; Bangham, C.R. HTLV-1-Tax and ICAM-1 act on T-cell signal pathways to polarize the microtubule-organizing center at the virological synapse. Blood 2009, 114, 1016-1025. [CrossRef] [PubMed]

32. Van Prooyen, N.; Gold, H.; Andresen, V.; Schwartz, O.; Jones, K.; Ruscetti, F.; Lockett, S.; Gudla, P.; Venzon, D.; Franchini, G. Human T-cell leukemia virus type 1 p8 protein increases cellular conduits and virus transmission. Proc. Natl. Acad. Sci. USA 2010, 107, 20738-20743. [CrossRef] [PubMed]

33. Jones, K.S.; Green, P.L. Cloaked virus slips between cells. Nat. Med. 2010, 16, 25-27. [CrossRef] [PubMed]

34. Pais-Correia, A.M.; Sachse, M.; Guadagnini, S.; Robbiati, V.; Lasserre, R.; Gessain, A.; Gout, O.; Alcover, A.; Thoulouze, M.I. Biofilm-like extracellular viral assemblies mediate HTLV-1 cell-to-cell transmission at virological synapses. Nat. Med. 2010, 16, 83-89. [CrossRef] [PubMed] 
35. Sze, A.; Belgnaoui, S.M.; Olagnier, D.; Lin, R.; Hiscott, J.; van Grevenynghe, J. Host restriction factor SAMHD1 limits human $\mathrm{T}$ cell leukemia virus type 1 infection of monocytes via STING-mediated apoptosis. Cell Host Microbe 2013, 14, 422-434. [CrossRef] [PubMed]

36. Ooms, M.; Krikoni, A.; Kress, A.K.; Simon, V.; Munk, C. APOBEC3A, APOBEC3B, and APOBEC3H haplotype 2 restrict human T-lymphotropic virus type 1. J. Virol. 2012, 86, 6097-6108. [CrossRef] [PubMed]

37. Bai, X.T.; Nicot, C. miR-28-3p is a cellular restriction factor that inhibits human T cell leukemia virus, type 1 (HTLV-1) replication and virus infection. J. Biol. Chem. 2015, 290, 5381-5390. [CrossRef] [PubMed]

38. Twizere, J.C.; Kruys, V.; Lefebvre, L.; Vanderplasschen, A.; Collete, D.; Debacq, C.; Lai, W.S.; Jauniaux, J.C.; Bernstein, L.R.; Semmes, O.J.; et al. Interaction of retroviral Tax oncoproteins with tristetraprolin and regulation of tumor necrosis factor-alpha expression. J. Natl. Cancer Inst. 2003, 95, 1846-1859. [CrossRef] [PubMed]

39. Boxus, M.; Twizere, J.C.; Legros, S.; Kettmann, R.; Willems, L. Interaction of HTLV-1 Tax with minichromosome maintenance proteins accelerates the replication timing program. Blood $\mathbf{2 0 1 2}$, 119, 151-160. [CrossRef] [PubMed]

40. Miyazato, P.; Yasunaga, J.; Taniguchi, Y.; Koyanagi, Y.; Mitsuya, H.; Matsuoka, M. De novo human T-cell leukemia virus type 1 infection of human lymphocytes in NOD-SCID, common gamma-chain knockout mice. J. Virol. 2006, 80, 10683-10691. [CrossRef] [PubMed]

41. Taylor, G.P.; Goon, P.; Furukawa, Y.; Green, H.; Barfield, A.; Mosley, A.; Nose, H.; Babiker, A.; Rudge, P.; Usuku, K.; et al. Zidovudine plus lamivudine in Human T-Lymphotropic Virus type-I-associated myelopathy: A randomised trial. Retrovirology 2006, 3, e63. [CrossRef] [PubMed]

42. Trevino, A.; Parra, P.; Bar-Magen, T.; Garrido, C.; de Mendoza, C.; Soriano, V. Antiviral effect of raltegravir on HTLV-1 carriers. J. Antimicrobial Chemother. 2012, 67, 218-221. [CrossRef] [PubMed]

43. Asquith, B.; Zhang, Y.; Mosley, A.J.; de Lara, C.M.; Wallace, D.L.; Worth, A.; Kaftantzi, L.; Meekings, K.; Griffin, G.E.; Tanaka, Y.; et al. In vivo T lymphocyte dynamics in humans and the impact of human T-lymphotropic virus 1 infection. Proc. Natl. Acad. Sci. USA 2007, 104, 8035-8040. [CrossRef] [PubMed]

44. Debacq, C.; Asquith, B.; Kerkhofs, P.; Portetelle, D.; Burny, A.; Kettmann, R.; Willems, L. Increased cell proliferation, but not reduced cell death, induces lymphocytosis in bovine leukemia virus-infected sheep. Proc. Natl. Acad. Sci. USA 2002, 99, 10048-10053. [CrossRef] [PubMed]

45. Ratner, L.; Philpott, T.; Trowbridge, D.B. Nucleotide sequence analysis of isolates of human T-lymphotropic virus type 1 of diverse geographical origins. AIDS Res. Hum. Retrovir. 1991, 7 , 923-941. [CrossRef] [PubMed]

46. Gillet, N.A.; Malani, N.; Melamed, A.; Gormley, N.; Carter, R.; Bentley, D.; Berry, C.; Bushman, F.D.; Taylor, G.P.; Bangham, C.R. The host genomic environment of the provirus determines the abundance of HTLV-1-infected T-cell clones. Blood 2011, 117, 3113-3122. [CrossRef] [PubMed] 
47. Gillet, N.A.; Gutierrez, G.; Rodriguez, S.M.; de Brogniez, A.; Renotte, N.; Alvarez, I.; Trono, K.; Willems, L. Massive depletion of bovine leukemia virus proviral clones located in genomic transcriptionally active sites during primary infection. PLoS Pathog. 2013, 9, e1003687. [CrossRef] [PubMed]

48. Reid, R.L.; Lindholm, P.F.; Mireskandari, A.; Dittmer, J.; Brady, J.N. Stabilization of wild-type p53 in human T-lymphocytes transformed by HTLV-I. Oncogene 1993, 8, 3029-3036. [PubMed]

49. Takachi, T.; Takahashi, M.; Takahashi-Yoshita, M.; Higuchi, M.; Obata, M.; Mishima, Y.; Okuda, S.; Tanaka, Y.; Matsuoka, M.; Saitoh, A.; et al. Human T-cell leukemia virus type 1 Tax oncoprotein represses the expression of the BCL11B tumor suppressor in T-cells. Cancer Sci. 2015, 106, 461-465. [CrossRef] [PubMed]

50. Yeung, M.L.; Yasunaga, J.; Bennasser, Y.; Dusetti, N.; Harris, D.; Ahmad, N.; Matsuoka, M.; Jeang, K.T. Roles for microRNAs, miR-93 and miR-130b, and tumor protein 53-induced nuclear protein 1 tumor suppressor in cell growth dysregulation by human T-cell lymphotrophic virus 1 . Cancer Res. 2008, 68, 8976-8985. [CrossRef] [PubMed]

51. Boxus, M.; Twizere, J.C.; Legros, S.; Dewulf, J.F.; Kettmann, R.; Willems, L. The HTLV-1 Tax interactome. Retrovirology 2008, 5, e76. [CrossRef] [PubMed]

52. Jin, D.Y.; Spencer, F.; Jeang, K.T. Human T cell leukemia virus type 1 oncoprotein Tax targets the human mitotic checkpoint protein MAD1. Cell 1998, 93, 81-91. [CrossRef]

53. Kinjo, T.; Ham-Terhune, J.; Peloponese, J.M., Jr.; Jeang, K.T. Induction of reactive oxygen species by human T-cell leukemia virus type 1 tax correlates with DNA damage and expression of cellular senescence marker. J. Virol. 2010, 84, 5431-5437. [CrossRef] [PubMed]

54. Grossman, W.J.; Kimata, J.T.; Wong, F.H.; Zutter, M.; Ley, T.J.; Ratner, L. Development of leukemia in mice transgenic for the tax gene of human T-cell leukemia virus type I. Proc. Natl. Acad. Sci. USA 1995, 92, 1057-1061. [CrossRef] [PubMed]

55. Hasegawa, H.; Sawa, H.; Lewis, M.J.; Orba, Y.; Sheehy, N.; Yamamoto, Y.; Ichinohe, T.; Tsunetsugu-Yokota, Y.; Katano, H.; Takahashi, H.; et al. Thymus-derived leukemia-lymphoma in mice transgenic for the Tax gene of human T-lymphotropic virus type I. Nat. Med. 2006, 12, 466-472. [CrossRef] [PubMed]

56. Ohsugi, T.; Kumasaka, T.; Okada, S.; Urano, T. The Tax protein of HTLV-1 promotes oncogenesis in not only immature T cells but also mature T cells. Nat. Med. 2007, 13, 527-528. [CrossRef] [PubMed]

57. Chaib-Mezrag, H.; Lemacon, D.; Fontaine, H.; Bellon, M.; Bai, X.T.; Drac, M.; Coquelle, A.; Nicot, C. Tax impairs DNA replication forks and increases DNA breaks in specific oncogenic genome regions. Mol. Cancer 2014, 13, 205. [CrossRef] [PubMed]

58. Marriott, S.J.; Semmes, O.J. Impact of HTLV-I Tax on cell cycle progression and the cellular DNA damage repair response. Oncogene 2005, 24, 5986-5995. [CrossRef] [PubMed]

59. Bellon, M.; Baydoun, H.H.; Yao, Y.; Nicot, C. HTLV-I Tax-dependent and -independent events associated with immortalization of human primary T lymphocytes. Blood 2010, 115, 2441-2448. [CrossRef] [PubMed] 
60. Nakagawa, M.; Schmitz, R.; Xiao, W.; Goldman, C.K.; Xu, W.; Yang, Y.; Yu, X.; Waldmann, T.A.; Staudt, L.M. Gain-of-function CCR4 mutations in adult T cell leukemia/lymphoma. J. Exp. Med. 2014, 211, 2497-2505. [CrossRef] [PubMed]

61. Shannon, K.M. CCR4 drives ATLL jail break. J. Exp. Med. 2014, 211, 2485. [CrossRef] [PubMed]

62. Furukawa, Y.; Kubota, R.; Tara, M.; Izumo, S.; Osame, M. Existence of escape mutant in HTLV-I tax during the development of adult T-cell leukemia. Blood 2001, 97, 987-993. [CrossRef] [PubMed]

63. Koiwa, T.; Hamano-Usami, A.; Ishida, T.; Okayama, A.; Yamaguchi, K.; Kamihira, S.; Watanabe, T. 5'-long terminal repeat-selective $\mathrm{CpG}$ methylation of latent human T-cell leukemia virus type 1 provirus in vitro and in vivo. J. Virol. 2002, 76, 9389-9397. [CrossRef] [PubMed]

64. Takeda, S.; Maeda, M.; Morikawa, S.; Taniguchi, Y.; Yasunaga, J.; Nosaka, K.; Tanaka, Y.; Matsuoka, M. Genetic and epigenetic inactivation of tax gene in adult T-cell leukemia cells. Int. J. Cancer 2004, 109, 559-567. [CrossRef] [PubMed]

65. Taniguchi, Y.; Nosaka, K.; Yasunaga, J.; Maeda, M.; Mueller, N.; Okayama, A.; Matsuoka, M. Silencing of human T-cell leukemia virus type I gene transcription by epigenetic mechanisms. Retrovirology 2005, 2, e64. [CrossRef] [PubMed]

66. Jacobson, S.; Shida, H.; McFarlin, D.E.; Fauci, A.S.; Koenig, S. Circulating CD8+ cytotoxic T lymphocytes specific for HTLV-I pX in patients with HTLV-I associated neurological disease. Nature 1990, 348, 245-248. [CrossRef] [PubMed]

67. Kannagi, M.; Harada, S.; Maruyama, I.; Inoko, H.; Igarashi, H.; Kuwashima, G.; Sato, S.; Morita, M.; Kidokoro, M.; Sugimoto, M.; et al. Predominant recognition of human $\mathrm{T}$ cell leukemia virus type I (HTLV-I) pX gene products by human CD8+ cytotoxic T cells directed against HTLV-I-infected cells. Int. Immunol. 1991, 3, 761-767. [CrossRef] [PubMed]

68. Kannagi, M.; Matsushita, S.; Harada, S. Expression of the target antigen for cytotoxic T lymphocytes on adult T-cell-leukemia cells. Int. J. Cancer 1993, 54, 582-588. [CrossRef] [PubMed]

69. Satou, Y.; Yasunaga, J.; Yoshida, M.; Matsuoka, M. HTLV-I basic leucine zipper factor gene mRNA supports proliferation of adult T cell leukemia cells. Proc. Natl. Acad. Sci. USA 2006, 103, 720-725. [CrossRef] [PubMed]

70. Macnamara, A.; Rowan, A.; Hilburn, S.; Kadolsky, U.; Fujiwara, H.; Suemori, K.; Yasukawa, M.; Taylor, G.; Bangham, C.R.; Asquith, B. HLA class I binding of HBZ determines outcome in HTLV-1 infection. PLoS Pathog. 2010, 6, e1001117. [CrossRef] [PubMed]

71. Hilburn, S.; Rowan, A.; Demontis, M.A.; MacNamara, A.; Asquith, B.; Bangham, C.R.; Taylor, G.P. In vivo expression of human T-lymphotropic virus type 1 basic leucine-zipper protein generates specific CD8+ and CD4+ T-lymphocyte responses that correlate with clinical outcome. J. Infect. Dis. 2011, 203, 529-536. [CrossRef] [PubMed]

72. Usui, T.; Yanagihara, K.; Tsukasaki, K.; Murata, K.; Hasegawa, H.; Yamada, Y.; Kamihira, S. Characteristic expression of HTLV-1 basic zipper factor (HBZ) transcripts in HTLV-1 provirus-positive cells. Retrovirology 2008, 5, e34. [CrossRef] [PubMed] 
73. Matsuoka, M.; Green, P.L. The HBZ gene, a key player in HTLV-1 pathogenesis. Retrovirology 2009, 6, e71. [CrossRef] [PubMed]

74. Arnold, J.; Zimmerman, B.; Li, M.; Lairmore, M.D.; Green, P.L. Human T-cell leukemia virus type-1 antisense-encoded gene, Hbz, promotes T-lymphocyte proliferation. Blood 2008, 112, 3788-3797. [CrossRef] [PubMed]

75. Matsuoka, M.; Jeang, K.T. Human T-cell leukemia virus type 1 (HTLV-1) and leukemic transformation: Viral infectivity, Tax, HBZ and therapy. Oncogene 2011, 30, 1379-1389. [CrossRef] [PubMed]

76. Andrade, R.G.; Goncalves Pde, C.; Ribeiro, M.A.; Romanelli, L.C.; Ribas, J.G.; Torres, E.B.; Carneiro-Proietti, A.B.; Barbosa-Stancioli, E.F.; Martins, M.L. Strong correlation between tax and HBZ mRNA expression in HAM/TSP patients: Distinct markers for the neurologic disease. J. Clin. Virol. 2013, 56, 135-140. [CrossRef] [PubMed]

77. Saito, M.; Matsuzaki, T.; Satou, Y.; Yasunaga, J.; Saito, K.; Arimura, K.; Matsuoka, M.; Ohara, Y. In vivo expression of the HBZ gene of HTLV-1 correlates with proviral load, inflammatory markers and disease severity in HTLV-1 associated myelopathy/tropical spastic paraparesis (HAM/TSP). Retrovirology 2009, 6, e19. [CrossRef] [PubMed]

78. Sun, S.C.; Yamaoka, S. Activation of NF-kappaB by HTLV-I and implications for cell transformation. Oncogene 2005, 24, 5952-5964. [CrossRef] [PubMed]

79. Pujari, R.; Hunte, R.; Thomas, R.; van der Weyden, L.; Rauch, D.; Ratner, L.; Nyborg, J.K.; Ramos, J.C.; Takai, Y.; Shembade, N. Human T-cell leukemia virus type 1 (HTLV-1) tax requires CADM1/TSLC1 for inactivation of the NF-kappaB inhibitor A20 and constitutive NF-kappaB signaling. PLoS Pathog. 2015, 11, e1004721. [CrossRef] [PubMed]

80. Harhaj, E.W.; Harhaj, N.S. Mechanisms of persistent NF-kappaB activation by HTLV-I tax. IUBMB Life 2005, 57, 83-91. [CrossRef] [PubMed]

81. Lavorgna, A.; Matsuoka, M.; Harhaj, E.W. A critical role for IL-17RB signaling in HTLV-1 tax-induced NF-kappaB activation and T-cell transformation. PLoS Pathog. 2014, 10, e1004418. [CrossRef] [PubMed]

82. Lavorgna, A.; Harhaj, E.W. Regulation of HTLV-1 tax stability, cellular trafficking and NF-kappaB activation by the ubiquitin-proteasome pathway. Viruses 2014, 6, 3925-3943. [CrossRef] [PubMed]

83. Karin, M. NF-kappaB as a critical link between inflammation and cancer. Cold Spring Harb. Perspect. Biol. 2009, 1. [CrossRef] [PubMed]

84. Xiao, G.; Fu, J. NF-kappaB and cancer: A paradigm of Yin-Yang. Am. J. Cancer Res. 2011, 1, 192-221. [PubMed]

85. Krueger, A.; Fas, S.C.; Giaisi, M.; Bleumink, M.; Merling, A.; Stumpf, C.; Baumann, S.; Holtkotte, D.; Bosch, V.; Krammer, P.H.; et al. HTLV-1 Tax protects against CD95-mediated apoptosis by induction of the cellular FLICE-inhibitory protein (c-FLIP). Blood 2006, 107, 3933-3939. [CrossRef] [PubMed]

86. Okamoto, K.; Fujisawa, J.; Reth, M.; Yonehara, S. Human T-cell leukemia virus type-I oncoprotein Tax inhibits Fas-mediated apoptosis by inducing cellular FLIP through activation of NF-kappaB. Genes Cells: Devoted Mol. Cell. Mech. 2006, 11, 177-191. [CrossRef] [PubMed] 
87. Tsukahara, T.; Kannagi, M.; Ohashi, T.; Kato, H.; Arai, M.; Nunez, G.; Iwanaga, Y.; Yamamoto, N.; Ohtani, K.; Nakamura, M.; et al. Induction of Bcl-x(L) expression by human T-cell leukemia virus type 1 Tax through NF-kappaB in apoptosis-resistant T-cell transfectants with Tax. J. Virol. 1999, 73, 7981-7987. [PubMed]

88. Nicot, C.; Mahieux, R.; Takemoto, S.; Franchini, G. Bcl-X(L) is up-regulated by HTLV-I and HTLV-II in vitro and in ex vivo ATLL samples. Blood 2000, 96, 275-281. [PubMed]

89. Swaims, A.Y.; Khani, F.; Zhang, Y.; Roberts, A.I.; Devadas, S.; Shi, Y.; Rabson, A.B. Immune activation induces immortalization of HTLV-1 LTR-Tax transgenic CD4+ T cells. Blood 2010, 116, 2994-3003. [CrossRef] [PubMed]

90. Macaire, H.; Riquet, A.; Moncollin, V.; Biemont-Trescol, M.C.; Duc Dodon, M.; Hermine, O.; Debaud, A.L.; Mahieux, R.; Mesnard, J.M.; Pierre, M.; et al. Tax protein-induced expression of antiapoptotic Bfl-1 protein contributes to survival of human T-cell leukemia virus type 1 (HTLV-1)-infected T-cells. J. Biol. Chem. 2012, 287, 21357-21370. [CrossRef] [PubMed]

91. Zhao, T.; Yasunaga, J.; Satou, Y.; Nakao, M.; Takahashi, M.; Fujii, M.; Matsuoka, M. Human T-cell leukemia virus type 1 bZIP factor selectively suppresses the classical pathway of NF-kappaB. Blood 2009, 113, 2755-2764. [CrossRef] [PubMed]

92. Zhi, H.; Yang, L.; Kuo, Y.L.; Ho, Y.K.; Shih, H.M.; Giam, C.Z. NF-kappaB hyper-activation by HTLV-1 tax induces cellular senescence, but can be alleviated by the viral anti-sense protein HBZ. PLoS Pathog. 2011, 7, e1002025. [CrossRef] [PubMed]

93. Ho, Y.K.; Zhi, H.; DeBiaso, D.; Philip, S.; Shih, H.M.; Giam, C.Z. HTLV-1 tax-induced rapid senescence is driven by the transcriptional activity of NF-kappaB and depends on chronically activated IKKalpha and p65/RelA. J. Virol. 2012, 86, 9474-9483. [CrossRef] [PubMed]

94. Philip, S.; Zahoor, M.A.; Zhi, H.; Ho, Y.K.; Giam, C.Z. Regulation of human T-lymphotropic virus type I latency and reactivation by HBZ and Rex. PLoS Pathog. 2014, 10, e1004040. [CrossRef] [PubMed]

95. Peloponese, J.M., Jr.; Jeang, K.T. Role for Akt/protein kinase B and activator protein-1 in cellular proliferation induced by the human T-cell leukemia virus type 1 tax oncoprotein. J. Biol. Chem. 2006, 281, 8927-8938. [CrossRef] [PubMed]

96. Jeong, S.J.; Dasgupta, A.; Jung, K.J.; Um, J.H.; Burke, A.; Park, H.U.; Brady, J.N. PI3K/AKT inhibition induces caspase-dependent apoptosis in HTLV-1-transformed cells. Virology 2008, 370, 264-272. [CrossRef] [PubMed]

97. Tomita, M.; Semenza, G.L.; Michiels, C.; Matsuda, T.; Uchihara, J.N.; Okudaira, T.; Tanaka, Y.; Taira, N.; Ohshiro, K.; Mori, N. Activation of hypoxia-inducible factor 1 in human T-cell leukaemia virus type 1-infected cell lines and primary adult T-cell leukaemia cells. Biochem. J. 2007, 406, 317-323. [PubMed]

98. Higuchi, M.; Takahashi, M.; Tanaka, Y.; Fujii, M. Downregulation of proapoptotic Bim augments IL-2-independent T-cell transformation by human T-cell leukemia virus type-1 Tax. Cancer Med. 2014, 3, 1605-1614. [CrossRef] [PubMed] 
99. Saito, K.; Saito, M.; Taniura, N.; Okuwa, T.; Ohara, Y. Activation of the PI3K-Akt pathway by human T cell leukemia virus type 1 (HTLV-1) oncoprotein Tax increases Bcl3 expression, which is associated with enhanced growth of HTLV-1-infected T cells. Virology 2010, 403, 173-180. [CrossRef] [PubMed]

100. Sugata, K.; Satou, Y.; Yasunaga, J.; Hara, H.; Ohshima, K.; Utsunomiya, A.; Mitsuyama, M.; Matsuoka, M. HTLV-1 bZIP factor impairs cell-mediated immunity by suppressing production of Th1 cytokines. Blood 2012, 119, 434-444. [CrossRef] [PubMed]

101. Tanaka-Nakanishi, A.; Yasunaga, J.; Takai, K.; Matsuoka, M. HTLV-1 bZIP factor suppresses apoptosis by attenuating the function of FoxO3a and altering its localization. Cancer Res. 2014, 74, 188-200. [CrossRef] [PubMed]

102. Matsumoto, J.; Ohshima, T.; Isono, O.; Shimotohno, K. HTLV-1 HBZ suppresses AP-1 activity by impairing both the DNA-binding ability and the stability of c-Jun protein. Oncogene 2005, 24, 1001-1010. [CrossRef] [PubMed]

103. Hivin, P.; Basbous, J.; Raymond, F.; Henaff, D.; Arpin-Andre, C.; Robert-Hebmann, V.; Barbeau, B.; Mesnard, J.M. The HBZ-SP1 isoform of human T-cell leukemia virus type I represses JunB activity by sequestration into nuclear bodies. Retrovirology 2007, 4, e14. [CrossRef] [PubMed]

104. Isono, O.; Ohshima, T.; Saeki, Y.; Matsumoto, J.; Hijikata, M.; Tanaka, K.; Shimotohno, K. Human T-cell leukemia virus type $1 \mathrm{HBZ}$ protein bypasses the targeting function of ubiquitination. J. Biol. Chem. 2008, 283, 34273-34282. [CrossRef] [PubMed]

105. Clerc, I.; Hivin, P.; Rubbo, P.A.; Lemasson, I.; Barbeau, B.; Mesnard, J.M. Propensity for HBZ-SP1 isoform of HTLV-I to inhibit c-Jun activity correlates with sequestration of c-Jun into nuclear bodies rather than inhibition of its DNA-binding activity. Virology 2009, 391, 195-202. [CrossRef] [PubMed]

106. Ohshima, T.; Mukai, R.; Nakahara, N.; Matsumoto, J.; Isono, O.; Kobayashi, Y.; Takahashi, S.; Shimotohno, K. HTLV-1 basic leucine-zipper factor, HBZ, interacts with MafB and suppresses transcription through a Maf recognition element. J. Cell. Biochem. 2010, 111, 187-194. [CrossRef] [PubMed]

107. Kashanchi, F.; Brady, J.N. Transcriptional and post-transcriptional gene regulation of HTLV-1. Oncogene 2005, 24, 5938-5951. [CrossRef] [PubMed]

108. Saggioro, D.; Barp, S.; Chieco-Bianchi, L. Block of a mitochondrial-mediated apoptotic pathway in Tax-expressing murine fibroblasts. Exp. Cell Res. 2001, 269, 245-255. [CrossRef] [PubMed]

109. Trevisan, R.; Daprai, L.; Acquasaliente, L.; Ciminale, V.; Chieco-Bianchi, L.; Saggioro, D. Relevance of CREB phosphorylation in the anti-apoptotic function of human T-lymphotropic virus type 1 tax protein in serum-deprived murine fibroblasts. Exp. Cell Res. 2004, 299, 57-67. [CrossRef] [PubMed]

110. Trevisan, R.; Daprai, L.; Paloschi, L.; Vajente, N.; Chieco-Bianchi, L.; Saggioro, D. Antiapoptotic effect of human T-cell leukemia virus type 1 tax protein correlates with its creb transcriptional activity. Exp. Cell Res. 2006, 312, 1390-1400. [CrossRef] [PubMed]

111. Saggioro, D. Anti-apoptotic effect of Tax: An NF-kappaB path or a CREB way? Viruses 2011, 3, 1001-1014. [CrossRef] [PubMed] 
112. Saggioro, D.; Silic-Benussi, M.; Biasiotto, R.; D’Agostino, D.M.; Ciminale, V. Control of cell death pathways by HTLV-1 proteins. Front. Biosci. 2009, 14, 3338-3351. [CrossRef]

113. Fukuda, R.I.; Tsuchiya, K.; Suzuki, K.; Itoh, K.; Fujita, J.; Utsunomiya, A.; Tsuji, T. Human T-cell leukemia virus type I tax down-regulates the expression of phosphatidylinositol 3,4,5-trisphosphate inositol phosphatases via the NF-kappaB pathway. J. Biol. Chem. 2009, 284, 2680-2689. [CrossRef] [PubMed]

114. Gaudray, G.; Gachon, F.; Basbous, J.; Biard-Piechaczyk, M.; Devaux, C.; Mesnard, J.M. The complementary strand of the human T-cell leukemia virus type 1 RNA genome encodes a bZIP transcription factor that down-regulates viral transcription. J. Virol. 2002, 76, 12813-12822. [CrossRef] [PubMed]

115. Lemasson, I.; Lewis, M.R.; Polakowski, N.; Hivin, P.; Cavanagh, M.H.; Thebault, S.; Barbeau, B.; Nyborg, J.K.; Mesnard, J.M. Human T-cell leukemia virus type 1 (HTLV-1) bZIP protein interacts with the cellular transcription factor CREB to inhibit HTLV-1 transcription. J. Virol. 2007, 81, 1543-1553. [CrossRef] [PubMed]

116. Clerc, I.; Polakowski, N.; Andre-Arpin, C.; Cook, P.; Barbeau, B.; Mesnard, J.M.; Lemasson, I. An interaction between the human $\mathrm{T}$ cell leukemia virus type 1 basic leucine zipper factor (HBZ) and the KIX domain of p300/CBP contributes to the down-regulation of tax-dependent viral transcription by HBZ. J. Biol. Chem. 2008, 283, 23903-23913. [CrossRef] [PubMed]

117. Cook, P.R.; Polakowski, N.; Lemasson, I. HTLV-1 HBZ protein deregulates interactions between cellular factors and the KIX domain of p300/CBP. J. Mol. Biol. 2011, 409, 384-398. [CrossRef] [PubMed]

118. Ma, G.; Yasunaga, J.; Fan, J.; Yanagawa, S.; Matsuoka, M. HTLV-1 bZIP factor dysregulates the Wnt pathways to support proliferation and migration of adult T-cell leukemia cells. Oncogene 2013, 32, 4222-4230. [CrossRef] [PubMed]

119. Arnulf, B.; Villemain, A.; Nicot, C.; Mordelet, E.; Charneau, P.; Kersual, J.; Zermati, Y.; Mauviel, A.; Bazarbachi, A.; Hermine, O. Human T-cell lymphotropic virus oncoprotein Tax represses TGF-beta 1 signaling in human T cells via c-Jun activation: A potential mechanism of HTLV-I leukemogenesis. Blood 2002, 100, 4129-4138. [CrossRef] [PubMed]

120. Lee, D.K.; Kim, B.C.; Brady, J.N.; Jeang, K.T.; Kim, S.J. Human T-cell lymphotropic virus type 1 tax inhibits transforming growth factor-beta signaling by blocking the association of Smad proteins with Smad-binding element. J. Biol. Chem. 2002, 277, 33766-33775. [CrossRef] [PubMed]

121. Mori, N.; Morishita, M.; Tsukazaki, T.; Giam, C.Z.; Kumatori, A.; Tanaka, Y.; Yamamoto, N. Human T-cell leukemia virus type I oncoprotein Tax represses Smad-dependent transforming growth factor beta signaling through interaction with CREB-binding protein/p300. Blood 2001, 97, 2137-2144. [CrossRef] [PubMed]

122. Zhao, T.; Satou, Y.; Sugata, K.; Miyazato, P.; Green, P.L.; Imamura, T.; Matsuoka, M. HTLV-1 bZIP factor enhances TGF-beta signaling through p300 coactivator. Blood 2011, 118, 1865-1876. [CrossRef] [PubMed] 
123. Kim, Y.M.; Geiger, T.R.; Egan, D.I.; Sharma, N.; Nyborg, J.K. The HTLV-1 tax protein cooperates with phosphorylated CREB, TORC2 and p300 to activate CRE-dependent cyclin D1 transcription. Oncogene 2010, 29, 2142-2152. [CrossRef] [PubMed]

124. Dellino, G.I.; Cittaro, D.; Piccioni, R.; Luzi, L.; Banfi, S.; Segalla, S.; Cesaroni, M.; Mendoza-Maldonado, R.; Giacca, M.; Pelicci, P.G. Genome-wide mapping of human DNA-replication origins: Levels of transcription at ORC1 sites regulate origin selection and replication timing. Genome Res. 2013, 23, 1-11. [CrossRef] [PubMed]

125. Ma, Y.; Zheng, S.; Wang, Y.; Zang, W.; Li, M.; Wang, N.; Li, P.; Jin, J.; Dong, Z.; Zhao, G. The HTLV-1 HBZ protein inhibits cyclin D1 expression through interacting with the cellular transcription factor CREB. Mol. Biol. Rep. 2013, 40, 5967-5975. [CrossRef] [PubMed]

126. Hagiya, K.; Yasunaga, J.; Satou, Y.; Ohshima, K.; Matsuoka, M. ATF3, an HTLV-1 bZip factor binding protein, promotes proliferation of adult T-cell leukemia cells. Retrovirology 2011, 8, e19. [CrossRef] [PubMed]

127. Tabakin-Fix, Y.; Azran, I.; Schavinky-Khrapunsky, Y.; Levy, O.; Aboud, M. Functional inactivation of p53 by human T-cell leukemia virus type 1 Tax protein: Mechanisms and clinical implications. Carcinogenesis 2006, 27, 673-681. [CrossRef] [PubMed]

128. Ariumi, Y.; Kaida, A.; Lin, J.Y.; Hirota, M.; Masui, O.; Yamaoka, S.; Taya, Y.; Shimotohno, K. HTLV-1 tax oncoprotein represses the p53-mediated trans-activation function through coactivator CBP sequestration. Oncogene 2000, 19, 1491-1499. [CrossRef] [PubMed]

129. Pise-Masison, C.A.; Mahieux, R.; Jiang, H.; Ashcroft, M.; Radonovich, M.; Duvall, J.; Guillerm, C.; Brady, J.N. Inactivation of p53 by human T-cell lymphotropic virus type 1 Tax requires activation of the NF-kappaB pathway and is dependent on p53 phosphorylation. Mol. Cell. Biol. 2000, 20, 3377-3386. [CrossRef] [PubMed]

130. Miyazato, A.; Sheleg, S.; Iha, H.; Li, Y.; Jeang, K.T. Evidence for NF-kappaB- and CBP-independent repression of p53's transcriptional activity by human T-cell leukemia virus type 1 Tax in mouse embryo and primary human fibroblasts. J. Virol. 2005, 79, 9346-9350. [CrossRef] [PubMed]

131. Gillet, N.; Carpentier, A.; Barez, P.Y.; Willems, L. WIP1 deficiency inhibits HTLV-1 Tax oncogenesis: Novel therapeutic prospects for treatment of ATL? Retrovirology 2012, 9, e115. [CrossRef] [PubMed]

132. Zane, L.; Yasunaga, J.; Mitagami, Y.; Yedavalli, V.; Tang, S.W.; Chen, C.Y.; Ratner, L.; Lu, X.; Jeang, K.T. Wip1 and p53 contribute to HTLV-1 Tax-induced tumorigenesis. Retrovirology 2012, 9, e114. [CrossRef] [PubMed]

133. Kasai, T.; Iwanaga, Y.; Iha, H.; Jeang, K.T. Prevalent loss of mitotic spindle checkpoint in adult T-cell leukemia confers resistance to microtubule inhibitors. J. Biol. Chem. 2002, 277, 5187-5193. [CrossRef] [PubMed]

134. Yasunaga, J.; Jeang, K.T. Viral transformation and aneuploidy. Environ. Mol. Mutagen. 2009, 50, 733-740. [CrossRef] [PubMed]

135. Liu, B.; Hong, S.; Tang, Z.; Yu, H.; Giam, C.Z. HTLV-I Tax directly binds the Cdc20-associated anaphase-promoting complex and activates it ahead of schedule. Proc. Natl. Acad. Sci. USA 2005, 102, 63-68. [CrossRef] [PubMed] 
136. Peloponese, J.M., Jr.; Haller, K.; Miyazato, A.; Jeang, K.T. Abnormal centrosome amplification in cells through the targeting of Ran-binding protein-1 by the human T cell leukemia virus type-1 Tax oncoprotein. Proc. Natl. Acad. Sci. USA 2005, 102, 18974-18979. [CrossRef] [PubMed]

137. Haoudi, A.; Semmes, O.J. The HTLV-1 tax oncoprotein attenuates DNA damage induced G1 arrest and enhances apoptosis in p53 null cells. Virology 2003, 305, 229-239. [CrossRef] [PubMed]

138. Park, H.U.; Jeong, J.H.; Chung, J.H.; Brady, J.N. Human T-cell leukemia virus type 1 Tax interacts with Chk1 and attenuates DNA-damage induced G2 arrest mediated by Chk1. Oncogene 2004, 23, 4966-4974. [CrossRef] [PubMed]

139. Park, H.U.; Jeong, S.J.; Jeong, J.H.; Chung, J.H.; Brady, J.N. Human T-cell leukemia virus type 1 Tax attenuates gamma-irradiation-induced apoptosis through physical interaction with Chk2. Oncogene 2006, 25, 438-447. [PubMed]

140. Gupta, S.K.; Guo, X.; Durkin, S.S.; Fryrear, K.F.; Ward, M.D.; Semmes, O.J. Human T-cell leukemia virus type 1 Tax oncoprotein prevents DNA damage-induced chromatin egress of hyperphosphorylated Chk2. J. Biol. Chem. 2007, 282, 29431-29440. [CrossRef] [PubMed]

141. Chandhasin, C.; Ducu, R.I.; Berkovich, E.; Kastan, M.B.; Marriott, S.J. Human T-cell leukemia virus type 1 tax attenuates the ATM-mediated cellular DNA damage response. J. Virol. 2008, 82, 6952-6961. [CrossRef] [PubMed]

142. Durkin, S.S.; Guo, X.; Fryrear, K.A.; Mihaylova, V.T.; Gupta, S.K.; Belgnaoui, S.M.; Haoudi, A.; Kupfer, G.M.; Semmes, O.J. HTLV-1 Tax oncoprotein subverts the cellular DNA damage response via binding to DNA-dependent protein kinase. J. Biol. Chem. 2008, 283, 36311-36320. [CrossRef] [PubMed]

143. Belgnaoui, S.M.; Fryrear, K.A.; Nyalwidhe, J.O.; Guo, X.; Semmes, O.J. The viral oncoprotein tax sequesters DNA damage response factors by tethering MDC1 to chromatin. J. Biol. Chem. 2010, 285, 32897-32905. [CrossRef] [PubMed]

144. Boxus, M.; Willems, L. How the DNA damage response determines the fate of HTLV-1 Tax-expressing cells. Retrovirology 2012, 9, e2. [CrossRef] [PubMed]

145. Vernin, C.; Thenoz, M.; Pinatel, C.; Gessain, A.; Gout, O.; Delfau-Larue, M.H.; Nazaret, N.; Legras-Lachuer, C.; Wattel, E.; Mortreux, F. HTLV-1 bZIP Factor HBZ Promotes Cell Proliferation and Genetic Instability by Activating OncomiRs. Cancer Res. 2014, 74, 6082-6093. [CrossRef] [PubMed]

146. Mukai, R.; Ohshima, T. HTLV-1 HBZ positively regulates the mTOR signaling pathway via inhibition of GADD34 activity in the cytoplasm. Oncogene 2014, 33, 2317-2328. [CrossRef] [PubMed]

147. Jeang, K.T.; Widen, S.G.; Semmes, O.J.t.; Wilson, S.H. HTLV-I trans-activator protein, tax, is a trans-repressor of the human beta-polymerase gene. Science 1990, 247, 1082-1084. [CrossRef] [PubMed]

148. Philpott, S.M.; Buehring, G.C. Defective DNA repair in cells with human T-cell leukemia/bovine leukemia viruses: Role of tax gene. J. Natl. Cancer Inst. 1999, 91, 933-942. [CrossRef] [PubMed] 
149. Kao, S.Y.; Marriott, S.J. Disruption of nucleotide excision repair by the human T-cell leukemia virus type 1 Tax protein. J. Virol. 1999, 73, 4299-4304. [PubMed]

150. Lemoine, F.J.; Kao, S.Y.; Marriott, S.J. Suppression of DNA repair by HTLV type 1 Tax correlates with Tax trans-activation of proliferating cell nuclear antigen gene expression. AIDS Res. Hum. Retrovir. 2000, 16, 1623-1627. [CrossRef] [PubMed]

151. Ducu, R.I.; Dayaram, T.; Marriott, S.J. The HTLV-1 Tax oncoprotein represses Ku80 gene expression. Virology 2011, 416, 1-8. [CrossRef] [PubMed]

152. Majone, F.; Jeang, K.T. Unstabilized DNA breaks in HTLV-1 Tax expressing cells correlate with functional targeting of Ku80, not PKcs, XRCC4, or H2AX. Cell Biosci. 2012, 2, e15. [CrossRef] [PubMed]

153. Baydoun, H.H.; Bai, X.T.; Shelton, S.; Nicot, C. HTLV-I tax increases genetic instability by inducing DNA double strand breaks during DNA replication and switching repair to NHEJ. PLoS ONE 2012, 7, e42226. [CrossRef] [PubMed]

154. Baydoun, H.H.; Pancewicz, J.; Nicot, C. Human T-lymphotropic type 1 virus p30 inhibits homologous recombination and favors unfaithful DNA repair. Blood 2011, 117, 5897-5906. [CrossRef] [PubMed]

(C) 2015 by the authors; licensee MDPI, Basel, Switzerland. This article is an open access article distributed under the terms and conditions of the Creative Commons Attribution license (http://creativecommons.org/licenses/by/4.0/). 